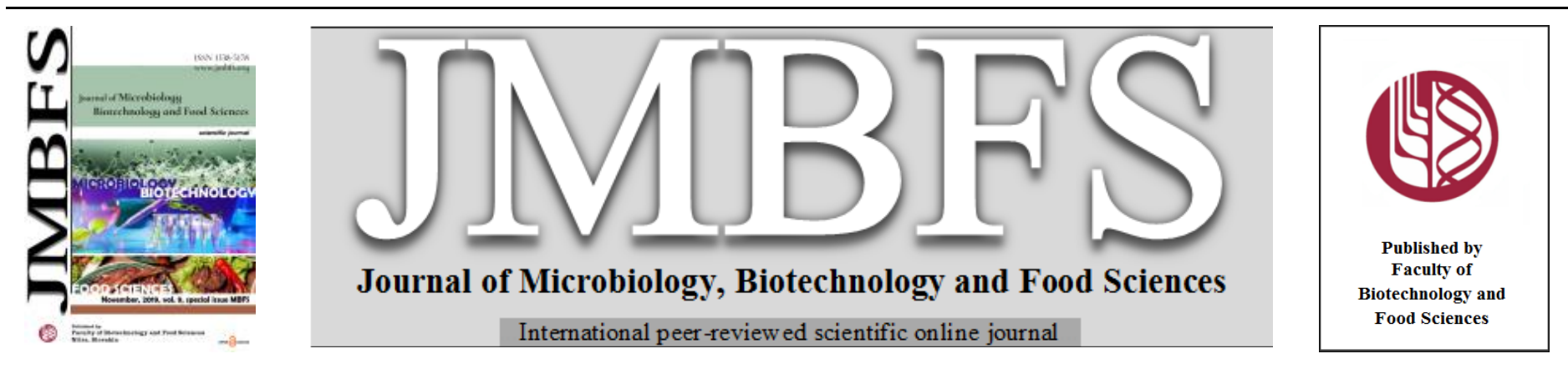

\title{
BY-PRODUCTS OF PLANT PROCESSING AND THEIR POSSIBLE APPLICATION INTO INNOVATIVE GLUTEN- FREE FOODSTUFFS
}

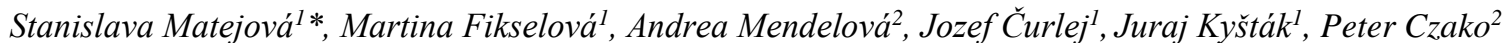

Address(es): Ing. Stanislava Matejová.

${ }^{1}$ Department of Food Hygiene and Safety, Faculty of Biotechnology and Food Sciences, Slovak University of Agriculture, Tr. A. Hlinku 2, 94976 Nitra, Slovak Republic.

${ }^{2}$ Department of Plant Products storage and Processing, Faculty of Biotechnology and Food Sciences, Slovak University of Agriculture, Tr. A. Hlinku 2, 94976 Nitra, Slovak Republic.

*Corresponding author: s.matejova@gmail.com

doi: 10.15414/jmbfs.2019.9.special.434-438

\section{ARTICLE INFO}

Received 20. 6. 2019

Revised 11.9. 2019

Accepted 9. 10. 2019

Published 8. 11. 2019

Regular article

OPEN $\partial_{\text {ACCESS }}$

\begin{abstract}
Fruit and vegetable waste represent a significant source of nutrients, such as polyphenols, minerals, fibre etc. For the food industry, they make a huge contribution from an economic point of view. In our work, we observed the by-products of plant processing as possible local sources of biologically active componets for the further application in gluten-free products. The total polyphenols, antioxidant activity and crude protein in eight samples of plant by-products (apple, buckwheat, tomato, chilli and grape varieties of Irsai Oliver, Red Traminer, Alibernet, Cabernet) were determined. The crude protein content ranged from $1.4 \%$ in buckwheat pomace to $15 \%$ in chilli pomace. The highest polyphenol content was found to be in Alibernet grape pomace $\left(256.9 \mathrm{mg} \cdot \mathrm{kg}^{-1}\right)$ and the lowest in chilli (155.15 mg.kg-1 $)$ pomace. The antioxidant activity of pomace ranged from 535.2 to $1359.49 \mathrm{mg} \cdot \mathrm{dm}^{-3}$. Gluten-free products such as muffins and knäckebrots were designed, into which by-products were applied in the amount of $3 \%$, except for chilli (0.5\% addition). Developed gluten-free products were evaluated by sensory and texture methods. As the sample with the highest sensory quality were concluded to be muffins made with $3 \%$ addition of Cabernet pomace. Grape and apple pomace can be recommended in gluten- free muffin production and tomato pomace in gluten free knäckebrot production.
\end{abstract}

Keywords: by-products, antioxidant activity, gluten free, pomace, polyphenols

\section{INTRODUCTION}

Around 89 million tons of food is wasted annually in the European Union and this value is expected to further increase by $40 \%$ in the next 4 years. Moreover, the World and Agriculture Organization calculated that one-third of the edible parts of food intended for human consumption get lost or wasted (Plazzotta et al., 2017). In recent years, waste management represents an important challenge in agricultural industries and markets. It demands an integrated approach in the context of reuse for the production of value-added products (Mythili et al., 2018). Recently, about one third of the fruit and vegetable, including

peels, skins, outer leaves and seeds, is wasted during preparation and processing, which poses a huge problem for both the environment and the food industry. However, many of these by-products can be used as additives to gluten-free food products, thus finding a second life (Conte et al., 2019). The vegetable wastes were usually discarded in vegetable markets. The vegetables are mainly composed of phytochemicals and many natural polysaccharides (Mythili et al., 2018). Option to increase the value of food wastes could be the transformation into products of commercial utility as they are very rich in bioactive compounds such as vitamins, minerals, amino acids, polyphenols etc. (Andrés et al., 2017). Currently there is a wide range of commercial extracts obtained from agri-food by-products and sold as antioxidants for the food and pharmaceutical industry (Andrés et al., 2017).

There is an association between an increased level of fruits and vegetables in the diet and a reduced risk of some life threatening diseases such as cardiovascular disease and cancer (Khan et al., 2018). Epidemiological evidence has widely associated phenolic-rich foods with the prevention of several chronic pathologies, including cardiovascular diseases, diabetes and neurodegenerative diseases, as well as some types of cancer. In this framework, the demand by consumers of food exerting beneficial effects on human health leads to the introduction into the global market of new products rich in phenolic compounds (Castello et al., 2018). The benefits of polyphenols in diets such as flavonoids, isoflavonoids, catechins, tannins, phenolic acids, stilbenoids and procyanidins have been widely studied for decades (Xiao, 2018).
At the present time, fruit and vegetable wastes and by-products are often discarded at the expense of the manufacturer. Use of the wastes as a source of polyphenols may be of considerable economic benefit to food processors. In addition, the antioxidant and cytoprotective activities of polyphenols in fruit and vegetable wastes and by-products are of utmost importance to substantiate their potential health benefits in human nutrition (Kabir et al., 2015).

Nowadays, consumers are interested in functional foods, and they are looking for tasty products which may also add to their natural body resistance, may help prevent and/or support therapies in selected diseases, support their physical fitness, and have a positive effect on their mental condition (Wójtowicz et al., 2018). Gluten-free products could in the past only be found in healthy food stores and online shops due to the moderate demand of only a small number of celiac patients, but nowadays a wide variety of gluten-free products is found in supermarkets, heading the increased demand (Wünsche et al., 2018).

The aim of this work was to test local and traditional by-products of plant processing as a source of biologically active components for their application into innovative gluten-free foodstuffs.

\section{MATERIAL AND METHODS}

\section{Material}

1. Pomace

The pomace were obtained as the waste products from the processing of the basic raw material from apples, grapes (Alibernet, Cabernet, Red Traminer and Irsai Oliver varieties), buckwheat, tomato and chilli processing. The pomaces (skins and seeds) were dried and ground in laboratory mill before application. Then they were used for their application into two bakery products (muffins, knäckebrot). 
2. Bakery products

The proposed products into which the pomace were applied were as following:

- $\quad$ „gluten free“ muffins - with application of grape and apple pomace (with $3 \%$ addition of pomace)

- $\quad$ „gluten free“ knäckebrot - with application of buckwheat, tomato and chilli pomace (with $3 \%$ addition of buckwheat and tomato pomace and $0.5 \%$ addition of chilli pomace)

The basic composition of the proposed products is listed in Table 1.

Table 1 The basic composition of products

$\begin{array}{ll}\text { Product } & \begin{array}{l}\text { Composition } \\ \text { rice flour, water, eggs, sunflower oil, sweetener: xylitol, } \\ \text { Muffins }\end{array} \\ \text { coconut sugar, bulking agent: E450, E500 } \\ \text { Knater, rice flour, buckwheat flakes, flax seeds, sunflower oil, } \\ \text { salt }\end{array}$

\section{Methods}

Determination of dry matter of pomace (ICC Standard No. 110/1)

The dry matter was determined by drying the sample to constant weight (gravimetrically).

\section{Determination of crude protein content (ICC Standard No. 105/2)}

The crude protein expresses the total crude protein content of the test sample. By multiplying the total $\mathrm{N}$ content in \%, determined by the classical Kjeldah method, by a factor of 5.7 we get the crude protein. The principle is that the organic matter base of the sample is oxidized with concentrated sulfuric acid in the presence of a catalyst. The product of the reaction is ammonium sulfate, from which ammonia is distilled off and then titrated Formula for calculation of crude protein:

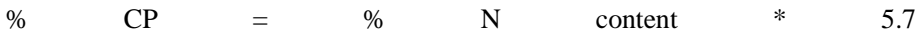
$\% \mathrm{CP}(100 \%$ Dry $)=\frac{C P * 100}{100-\text { moisture } \%}$

\section{Determination of total polyphenols in pomace}

Polyphenolic content was determined by the Folin - Ciocalteu method (Singleton and Rossi, 1965). The method is based on the reaction of FolinCiocalteu reagent with polyphenol to form a blue complex. The intensity of the blue is directly proportional to the polyphenols content. The evaluation was performed using a spectrophotometer at a wavelength of $700 \mathrm{~nm}$. The content of total polyphenols is expressed as the equivalent of gallic acid. The samples were extracted into ethanol and shaken for 24 hours.

\section{Measurement of antioxidant capacity by FOMO method in pomace}

The antioxidant activity was determined by the FOMO method (Prieto et al., 1999). The principle of this method is the reduction of Mo (VI) to Mo (V) by the action of reducing components in the presence of phosphorus. A green phosphomolybdenum complex is formed. The reducing ability of the compounds is expressed by the amount of ascorbic acid required to achieve the same effect. The samples were extracted into ethanol and shaken for 24 hours.

\section{Product evaluation}

\section{Texture measurement of developed food product}

The texture of the developed products was evaluated by the TA.XT Plus Texture Analyzer (Stable Micro Systems, Surrey, UK) according to the standard method AACC (74-09) expressed as the firmness of the muffin crumb (N):- the maximum force required to compress the product. For analysis, $36 \mathrm{~mm}$ rounded radius probe (P / 36R) was used. The HDP / BSK probe was used to determine the knäckebrots by which we tested the firmness of the samples.

\section{Sensory evaluation of food products}

A panel of skilled evaluators assessed the samples with a 5-point scale (1insufficient, 2- sufficient, 3- good, 4- very good, 5- excellent). The descriptors listed in Table 2 were used. For the sensory evaluation of the samples with the additions of the pomace, we used a point test that examines each designated descriptor in general or as partial properties (hardness, softness, etc.) (Horčin 2002).

In each group of products the control sample with a basic composition was prepared with no addition of pomace. The samples were evaluated by the increasing amount of added by-products in the products. The results of the sensory analysis were processed using the sensometric methods used - calculating the the standard deviation and the mean values.
Table 2 Sensory evaluated descriptors

\begin{tabular}{ccc} 
Descriptors & Muffins & Knäckebrots \\
1. & General appearance & General appearance \\
2. & Surface and properties of crust & Structure and surface \\
3. & Rising and appearance of & Fragility and brittleness \\
4. & crumb & Odor \\
5. & Odor & Taste \\
\hline
\end{tabular}

Statistical processing

The results of texture measurement were processed by programe Exponent.

\section{RESULTS AND DISCUSSION}

\section{Dry matter content of pomace}

In Figure 1 is shown dry matter content of pomace. The dry matter content ranged from $86 \%$ to $92 \%$. The lowest moisture (92\%) showed sample 3 (tomatoes) and the highest ( $86 \%$ ) sample 1 and 4 (apple and chilli).

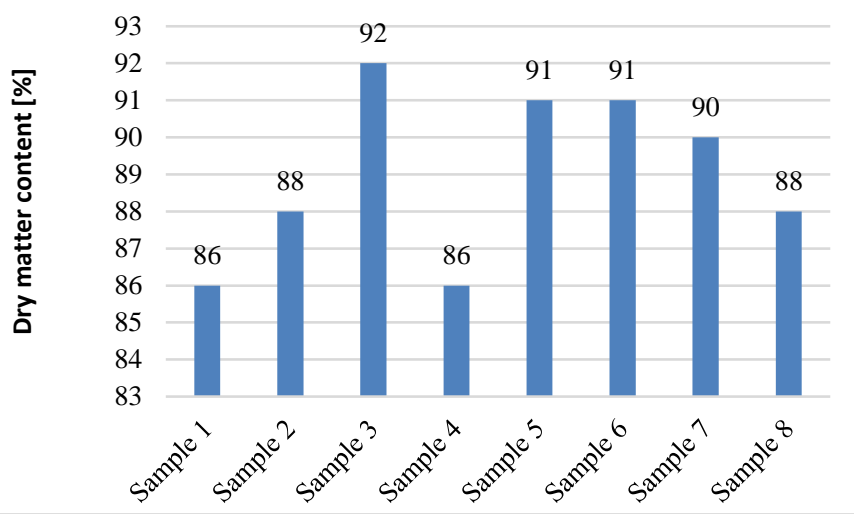

Figure 1 Dry matter content in pomace [\%]

Sample 1 (apple), sample 2 (buckwheat), sample 3 (tomatoes), sample 4 (chilli), sample 5 (Cabernet), sample 6 (Alibernet), sample 7 (Irsai Oliver), sample 8 (Traminer Red)

\section{Crude protein of pomace}

Food technology interventions have addressed mainly the shelf life and rheology properties of the gluten free products. Starchy gluten free baked goods lose freshness and accelerate staling during storage. In a gluten free system, the water is present at much higher level than in wheat dough and, therefore, full starch gelatinization has been observed in the product. Aroma loss, elasticity decrease, crust softening and crumb firming occur during staling (Gobbetti et al., 2017) One of the observed parameters in pomace raw materials was crude protein content. Pomace as observed plant sources are gluten free, therefore could serve as a protein source in gluten free products and diet. The highest source of protein was recorded sample of chilli $(15 \%)$.

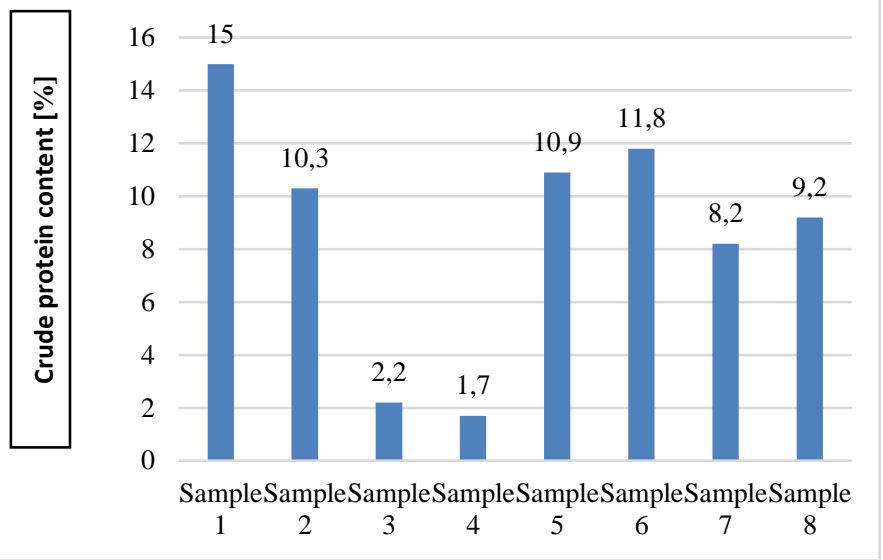

Figure 2 Mean crude protein content in pomace [\%]

Sample 1 (chilli), sample 2 (tomatoes), sample 3 (apple), sample 4 (buckwheat), sample 5 (Cabernet), sample 6 (Alibernet), sample 7 (Traminer Red), sample 8 (Irsai Oliver) 
From the results of Chouaibi et al. (2019) who determined total protein in red pepper seeds, we can compare that our chilli sample was lower in crude protein. The total protein in their study reached $28.33 \%$ but they used for calculation coefficient 6.25 . The total protein composition of Naga king chillies analyzed Ananthan et al. (2018), it was lowest in pericarp and highest in placenta (14.21 and $22.32 \mathrm{~g} / 100 \mathrm{~g}$ respectively).

Grape pomace showed comparable crude protein content to chilli, it ranged from $8.2 \%$ to $11.8 \%$. Grape pomace is also nutritionally valuable because of its polyphenol content, as shown in Fig. 3.

\section{Total polyphenols and antioxidant activity of pomace}

Content of total polyphenols in pomace ranged from $155.15 \mathrm{mg} \cdot \mathrm{kg}^{-1}$ to 256.9 $\mathrm{mg} \cdot \mathrm{kg}^{-1}$. The highest content was found to be in the sample of Alibernet grape pomace ( Fig.3)

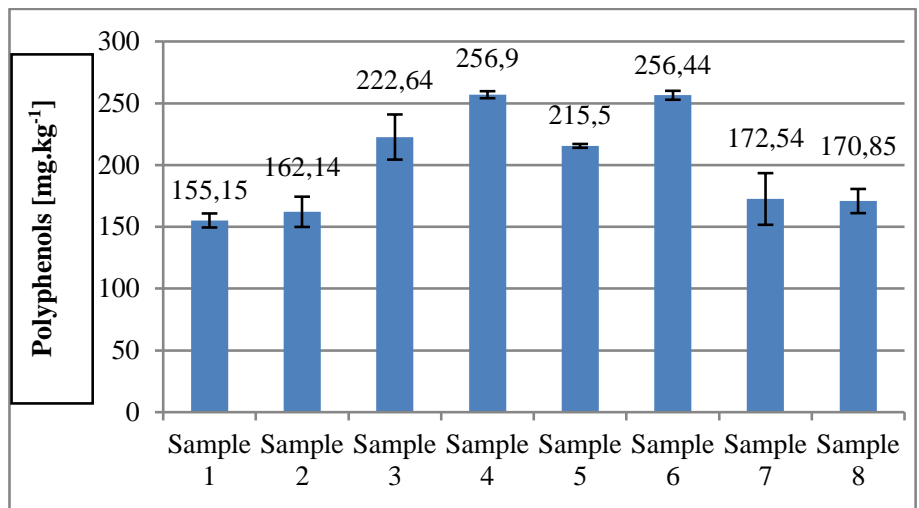

Figure 3 Total polyphenol content [mg.kg $\left.{ }^{-1}\right]$

Sample 1 (chilli), sample 2 (tomatoes), sample 3 (Cabernet), sample 4 (Alibernet), sample 5 (buckwheat), sample 6 (Red Traminer), sample 7 (Irsai Oliver), sample 8 (apples)

The interest on grape pomace as a potential source for the recovery of the polyphenols stems from the fact that this waste by-product has a significant proportion of polyphenols due to the incomplete maceration during the wine making process (Nayak et al., 2018). Our samples of grape pomace showed high contents of total polyphenols, they ranged from $172.54 \mathrm{mg} . \mathrm{kg}^{-1}$ to $256.9 \mathrm{mg} \cdot \mathrm{kg}^{-1}$ Very similar content of polyphenols showed sample 4 (Alibernet), $256.9 \mathrm{mg} \cdot \mathrm{kg}^{-1}$ and sample 6 (Red Traminer), $256.44 \mathrm{mg} \cdot \mathrm{kg}^{-1}$. Grape pomace is the main residue generated by the wine industry, consisting of three different components: seeds, stems, and skins. It is a very interesting waste because of the presence of a wide range of polyphenols, mainly composed of flavonoids including anthocyanins (Andrés et al., 2017), flavan-3-ols, flavonols and flavanols (Castello et al., 2018) such as condensed tannins, which are characterized by their high antioxidant and antimicrobial properties (Andrés et al., 2017).

Mudrić et al. (2017) identified total polyphenolic content and antioxidan activity in spice peppers, the total polyphenolic content ranged from 7.43 to $14.92 \mathrm{~g} \mathrm{GAE} / \mathrm{kg}$ dry matter. It was found relatively low correlation between total polyphenolic content and radical scavenging activity which might be explained by complex dependence between antioxidant activity and content of not only phenolic compounds but other peppers' constituents such as carotenoids, vitamins $\mathrm{C}$ and $\mathrm{E}$, and capsaicinoids. Our sample of chilli pomace contained the lowest content of polyphenols, $155.15 \mathrm{mg} \cdot \mathrm{kg}^{-1}$, but they were found to be interesting in terms of carotenoids (Matejová et al., 2017) and antioxidant activity (Fig. 4). Total carotenoids in our previous work determined in chilli pomace, was found to be $381.71 \mathrm{mg} \cdot \mathrm{kg}^{-1}$.

Sample of tomato pomace was comparable to chilli regarding the content of polyhenols $\left(162.14 \mathrm{mg} \cdot \mathrm{kg}^{-1}\right)$. Tomatoes are a rich source of lycopene which accounts for up to $98 \%$ of carotenoids in tomato (Allison and Simmons, 2015).

Polyphenols are known to be the secondary plant metabolites and they are the most desirable phytochemicals because of their strong antioxidant activity (Wójtowicz et al., 2018). Antioxidant activity of our samples ranged from 535.2 to $1359.49 \mathrm{mg} \cdot \mathrm{dm}^{-3}$. The highest antioxidant activity showed sample of grape pomace (Alibernet) and this sample was also the highest in content of polyphenols, followed by the sample of Cabernet and Red Traminer (Figure 4) The phytochemical compounds have demonstrated that they can decrease the risk of developing various chronic diseases due to their antioxidant and radicalscavenging activities (Raybaudi-Massilia et al., 2017) and in addition, plantderived ingredients possessing antioxidant and antimicrobial properties, have the advantage of being readily accepted by consumers, as they are considered natural compounds.

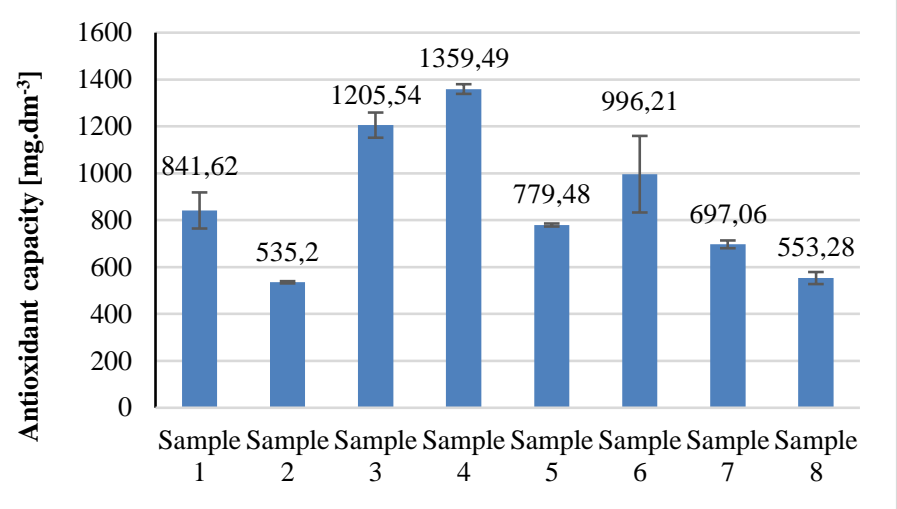

Figure 4 Antioxidant activity of pomace $\left[\mathrm{mg}^{\mathrm{d}} \mathrm{dm}^{-3}\right]$

Sample 1 (chilli), sample 2 (tomatoes), sample 3 (Cabernet), sample 4 (Alibernet), sample 5 (buckwheat), sample 6 (Red Traminer), sample 7 (Irsai Oliver), sample 8 (apples)

Different studies observed the composition and properties of apple pomace, revealing that it is an interesting raw material due to its content in phytochemicals such polyphenols with antioxidant and antiviral activities (Madrera et al., 2017). In our study, they showed to be not so rich source of antioxidants or polyphenols compared to the other monitored sources.

\section{Testing of pomace addition into gluten free muffins}

Muffins are a popular product because of their convenient to eat form and long shelf life. They are traditionally made from wheat flour which is deficient in lysine, tryptophan and in some minerals. Thus, muffins may become easily improved to meet special dietary or consumer needs (Antoniewska et al., 2018) Our muffins were designed with $3 \%$ addition of grape and apple pomace and evaluated by sensory and textural properties (tables 3,4 and figure 5).

Table 3 Results of sensory evaluation of muffins fortified by $3 \%$ addition of pomace (points median)

\begin{tabular}{lllllll}
\hline $\begin{array}{l}\text { Sample } \\
\text { Descriptors }\end{array}$ & $\mathbf{1}$ & $\mathbf{2}$ & $\mathbf{3}$ & $\mathbf{4}$ & $\mathbf{5}$ & $\mathbf{6}$ \\
1. General appearance & Median & & & & \\
2. Surface and properties of crust & 4 & 4 & 4 & 4 & 5 & 4 \\
3.Rising and appearance of crumb & 4 & 4 & 4 & 4 & 5 & 4 \\
4. Odor & 3 & 3 & 4 & 3 & 3 & 4 \\
5. Taste & 3 & 4 & 4 & 3 & 3 & 4 \\
Sum of points & 18 & 19 & 19 & 18 & 21 & 20 \\
SD & 0.55 & 0.45 & 0.45 & 0.55 & 1.10 & 0,00 \\
Average & 3.6 & 3.8 & 3.8 & 3.6 & 4.2 & 4 \\
Order & 4 & 3 & 3 & 4 & 1 & 2 \\
\hline Sample 1 (control), sample 2 ( Irsai Oliver), sample 3 (Red Traminer), sample 4 ( Alibernet), \\
sample 5 ( Cabernet), sample 6 (apple)
\end{tabular}


Table 4 Overall quality evaluation of muffins fortified by $3 \%$ addition of pomace (points)

\begin{tabular}{lcccccc}
\hline Samples & $\mathbf{1}$ & $\mathbf{2}$ & $\mathbf{3}$ & $\mathbf{4}$ & $\mathbf{5}$ & $\mathbf{6}$ \\
Sum of points & 90 & 97 & 92 & 93 & 107 & 96 \\
Median & 18 & 20 & 18 & 20 & 24 & 18 \\
Average & 18 & 19.4 & 18.4 & 18.6 & 21.4 & 19.2 \\
SD & 1.87 & 2.41 & 1.14 & 2.41 & 4.10 & 2.17 \\
Order & 6 & 2 & 5 & 4 & 1 & 3
\end{tabular}

Sample 1 (control), sample 2 (Irsai Oliver), sample 3 ( Red Traminer), sample 4 (Alibernet), sample 5 (Cabernet), sample 6 (apple)

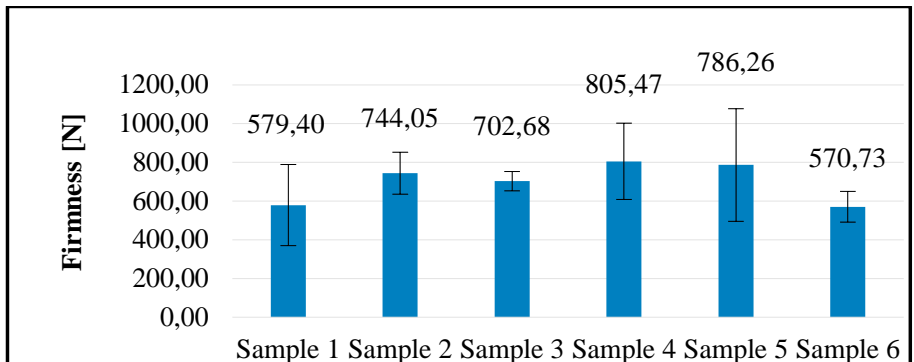

Figure 5 Textural properties of muffins $[\mathrm{N}]$

Sample 1 (control), sample 2 ( Irsai Oliver), sample 3 (Red Traminer), sample 4 (Alibernet), sample 5 ( Cabernet), sample 6 (apple)

As the sample with the highest sensory quality was evaluated sample of muffins with $3 \%$ addition of Cabernet pomace, with obtained points 107 and very interesting purple colour. This sample showed the highest firmness among all samples as well.

The addition of polyphenol compounds and fibre strongly impacts both the sensory properties and acceptability of products, and bitterness is one of the major problems when dealing with polyphenol-enriched functional products. Grape skins and seeds are rich sources of TDF. The use of grape by-products as a source of fibre affected the mouthfeel and textural properties of functional beverages and foods in terms of chalkiness, hardness and gumminess (Kuchtová et al., 2018; Torri et al., 2015) that was not confirmed in our case. The effects of partial replacement of wheat flour by cellulose fiber with different fiber length on rheological properties of wheat dough and qualitative parameters of baked rolls studied Lauková et al. (2017).

As the lowest quality sample with 90 points was found to be control one. This sample also showed the second lowest firmness. Firmness of developed products with addition of grape pomace inreased, it ranged from 702.68 to 805.47 $\mathrm{N}$, compared to control, $579.4 \mathrm{~N}$.

Muffins with the addition of apple pomace (sample 6) showed the lowest firmness (Fig. 5), this result is comparable to the control sample. Following the sensory evaluation, apple pomace provided to the product pleasant taste and color, that was sensorically evaluated positively, so we can conclude the improvement of our products with the addition of pomace.

\section{Gluten free knäckebrots with addition of pomace}

Knäckebrots regarding the senory point of view were positively evaluated in basic composition (control), this product also achieved low firmness (figure 6) at the texture measurement. Followed the sample with tomato pomace addition (91 points, compared to control 106 points) that was evaluated very positively as well (table 5 and 6). The addition of chilli pomace (sample 4) provided to the products interesting color and taste. Due to the high sharpness of the pomace, they could be added to the products only in the amount of $0.5 \%$. This sample achieved the best textural properties.

Knäckebrots made by the addition of buckwheat pomace were assessed with the lowest quality. Matejová et al. (2016) applied the buckwheat by-products to the gluten-free breads and it was noted an increased sharpness of the final product, that could be caused by the presence of undissolved fibre in the pomace.

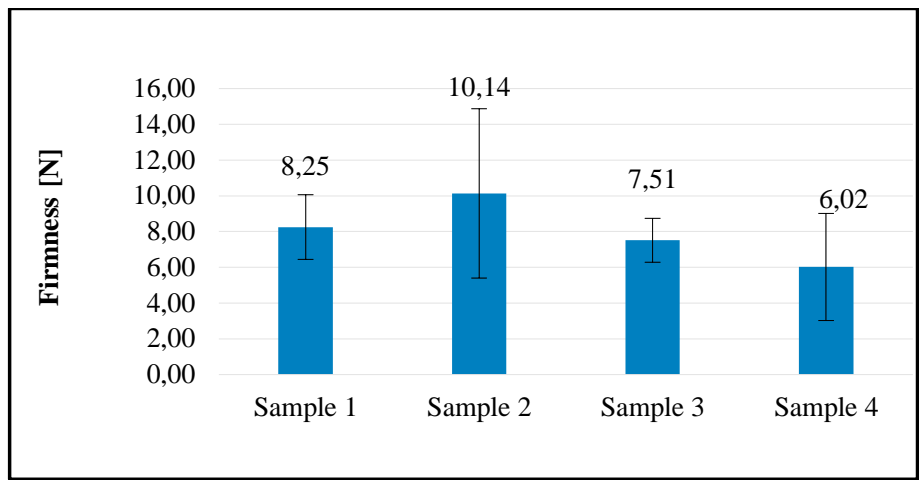

Figure 6 Results of texture measurement in knäckebrots [N]

Sample 1 (control), sample 2 (3\% of buckwheat pomace), sample 3 (3\% of tomato pomace), sample 4 (0.5\% chilli pomace)

By the textrural evaluation it was found that the firmness ranged from 6.02 to $10.14 \mathrm{~N}$. By the addition of buckwheat pomace the firmness increased, tomato and chilli slightly decreased firmness of the product (Fig. 6).

Table 5 Results of sensory evaluation of knäckebrots (points)

\begin{tabular}{lcccc}
\hline $\begin{array}{l}\text { Samples } \\
\text { Descriptors }\end{array}$ & $\mathbf{1}$ & $\mathbf{2}$ & $\mathbf{3}$ & $\mathbf{4}$ \\
1. General appearance & 4 & 3 & 5 & 4 \\
2. Structure and surface & 4 & 3 & 4 & 4 \\
3.Fragility and brittleness & 4 & 4 & 4 & 3 \\
4. Odor & 5 & 3 & 3 & 3 \\
5. Taste & 5 & 4 & 4 & 4 \\
Sum of points & 22 & 17 & 20 & 18 \\
SD & 0.55 & 0.55 & 0.71 & 0.55 \\
Average & 4.4 & 3.4 & 4 & 3.6 \\
Order & 1 & 4 & 2 & 3 \\
\hline
\end{tabular}

Sample 1 (control), sample 2 (3\% of buckwheat pomace), sample 3 (3\% of tomato pomace), sample 4 (0.5\% chilli pomace)

Table 6 Overall quality evaluation of knäckebrot (points)

\begin{tabular}{lcccc}
\hline Samples & $\mathbf{1}$ & $\mathbf{2}$ & $\mathbf{3}$ & $\mathbf{4}$ \\
Sum of points & 106 & 87 & 91 & 88 \\
Median & 21 & 18 & 18 & 18 \\
Average & 21.2 & 17.4 & 18.2 & 17.6 \\
SD & 1.30 & 2.51 & 2.59 & 1.52 \\
Order & 1 & 4 & 2 & 3
\end{tabular}

Sample 1 (control), sample 2 (3\% of buckwheat pomace), sample 3 (3\% of tomato pomace), sample 4 (0.5\% chilli pomace)

\section{CONCLUSION}

Possible utilization of plant by-products (apple, buckwheat, tomato, chilli and grape) in the development of gluten-free products was evaluated in this work. We can conclude that pomace is an interesting and cheap source of polyphenols, crude protein and is showing interesting antioxidant activity, that are important parameters for gluten free food, expecting to reflect them not only in nutritional value of the products but also improving sensory quality. We recommend to apply grape and apple pomace especially in muffin production and tomato pomace in knäckebrot production.

These results can be used for better examination/utilization of local food waste from traditional and local vegetable and fruits processing in the further development of foodstuffs intended for particular nutritional uses that are currently considered to be more expensive, sensory and nutritionally less attractive than common food. 
Acknowledgments: This work was supported by grant VEGA No. 1/0280/17 and KEGA č.017SPU-4/2019.

\section{REFERENCES}

ALLISON, B. J. AND SIMMONS, CH. W. 2017. Valorization of tomato pomace by sequential lycopene extraction and anaerobic digestion. Biomass and Bioenergy 105, pp. 331-341. DOI http://dx.doi.org/10.1016/j.biombioe.2017.07.019. ISSN 09619534.

ANANTHAN, R., SUBHASH, K., LONGVAH, T. 2018. Capsaicinoids, amino acid and fatty acid profiles in different fruit components of the world hottest Naga king chilli ( Capsicum chinense Jacq). Food Chemistry, 238, 51-57. DOI http://dx.doi.org/10.1016/j.foodchem.2016.12.073. ISSN 03088146.

ANDRÉS, A. I., PETRÓN, M. J., ADÁMEZ, J. D., LÓPEZ, M. AND TIMÓN, M. L. 2017. Food by-products as potential antioxidant and antimicrobia additives in chill stored raw lamb patties. Meat Science, 129, pp. 62-70. DOI http://dx.doi.org/10.1016/j.meatsci.2017.02.013. ISSN 03091740.

ANTONIEWSKA, A., RUTKOWSKA, J., PINEDA, M. M. AND ADAMSKA, A. 2018. Antioxidative, nutritional and sensory properties of muffins with buckwheat flakes and amaranth flour blend partially substituting for wheat flour. LWT, 89, pp. 217-223. DOI: http://dx.doi.org/10.1016/j.lwt.2017.10.039. ISSN 00236438.

CASTELlO, F., COSTABILE, G., BRESCIANI, L. et al. 2018. Bioavailability and pharmacokinetic profile of grape pomace phenolic compounds in humans Archives of Biochemistry and Biophysics, 646, pp. 1-9. DOI http://dx.doi.org/10.1016/j.abb.2018.03.021. ISSN 00039861.

CONTE, P., FADDA, C., DRABIŃSKA，N., KRUPA-KOZAK, U. 2019 Technological and Nutritional Challenges, and Novelty in Gluten-Free Breadmaking: a Review. Polish Journal of Food and Nutrition Sciences, 69(1), 5-21. DOI: http://dx.doi.org/10.31883/pjfns-2019-0005. ISSN 12300322.

GOBBETTI, M., PONTONIO, E., FILANNINO, P., RIZZELLO, C. G., DE ANGELIS, M., DI CAGNO, R. 2017. How to improve the gluten-free diet: The state of the art from a food science perspective. Food Research International. DOI: http://dx.doi.org/10.1016/j.foodres.2017.04.010. ISSN 09639969.

HORČIN V. 2002. Sensory evaluation of foodstuffs. Nitra: SPU.

CHOUAIBI, M., REZIG, L., HAMDI, S., FERRARI, G. 2019. Chemical characteristics and compositions of red pepper seed oils extracted by different methods. Industrial Crops and Products, 128, 363-370. DOI: http://dx.doi.org/10.1016/j.indcrop.2018.11.030. ISSN 09266690.

KHAN, M. K., AHMAD, K., HASSAN, S., et al. 2018. Effect of novel technologies on polyphenols during food processing. Innovative Food Science \& Emerging Technologies, 45, pp. 361-381. DOI: http://dx.doi.org/10.1016/j.ifset.2017.12.006. ISSN 14668564.

KUCHTOVÁ, V., KOHAJDOVÁ, Z., KAROVIČOVÁ, J., LAUKOVÁ, M. 2018. Physical, Textural and Sensory Properties of Cookies Incorporated with Grape Skin and Seed Preparations. Polish Journal of Food and Nutrition Sciences, 68(4), 309-317. DOI: http://dx.doi.org/10.2478/pjfns-2018-0004. ISSN 2083-6007.

LAUKOVÁ, M., KOHAJDOVÁ, Z., KAROVIČOVÁ, J. et al. 2017. Effects of cellulose fiber with different fiber length on rheological properties of wheat dough and quality of baked rolls. Food Science and Technology International, 23, 6: pp. 490-499.

MADRERA, R. R., PANDO BEDRIÑANA, R., SUÁREZ VALLES, B. 2017. Enhancement of the nutritional properties of apple pomace by fermentation with autochthonous yeasts. LWT - Food Science and Technology, 79, pp. 27-33. DOI: http://dx.doi.org/10.1016/j.lwt.2017.01.021. ISSN 00236438.

MATEJOVÁ, S., FIKSELOVÁ, M., ČURLEJ, J. AND CZAKO, P. 2016. Application of by-products in the development of foodstuffs for particular nutritional uses. Journal of Central European Agriculture, 17(4), pp. 1306-1319. DOI: http://dx.doi.org/10.5513/JCEA01/17.4.1850. ISSN 1332-9049.

MATEJOVÁ, S., FIKSELOVÁ, M., MENDELOVÁ, A., MARTIŠOVÁ, P. 2017. Use of carotenoid rich by-products in the production of food for particular nutritional uses. Food safety and control. SPU v Nitre, pp. 279-283. ISBN 97880-552-1649-2.

MUDRIĆ, S. Ž., GAŠIC, U. M., DRAMIĆANIN, A. M., ĆIRIĆ, I. Ž. et al. 2017. The polyphenolics and carbohydrates as indicators of botanical and geographical origin of Serbian autochthonous clones of red spice paprika. Food Chemistry, 217, pp. 705-715.

MYTHILI, R., SELVANKUMAR, T., SRINIVASAN, P. et al. 2018. Biogenic synthesis, characterization and antibacterial activity of gold nanoparticles synthesised from vegetable waste. Journal of Molecular Liquids, 262, pp. 318321. DOI: http://dx.doi.org/10.1016/j.molliq.2018.04.087. ISSN 01677322.

NAYAK, A., BHUSHAN, B., ROSALES, A. et al. 2018. Valorisation potential of Cabernet grape pomace for the recovery of polyphenols: Process intensification, optimisation and study of kinetics. Food and Bioproducts Processing, 109, pp. 74-85. DOI: http://dx.doi.org/10.1016/j.fbp.2018.03.004. ISSN 09603085.

PLAZZOTTA, S., MANZOCCO, L., NICOLI, M. C. 2017. Fruit and vegetable waste management and the challenge of fresh-cut salad. Trends in Food Science
\& Technology, 63, pp. 51-59. DOI: http://dx.doi.org/10.1016/j.tifs.2017.02.013 ISSN 09242244

PRIETO, P., PINEDA, M., AGUILAR, M. 1999. Spectrophotometric quantitation of antioxidant capacity through the formation of a phosphomolybdenum complex: specific application to the determination of vitamin E. Analytical Biochemistry, 269, pp. 337-341.

RAYBAUDI-MASSILIA, R., SUÁREZ, A. I., ARVELO, F. et al. 2017. Cytotoxic, antioxidant and antimicrobial properties of red sweet pepper (Capsicum annuum L. var. Llanerón) extracts: In vitro study. International Journal of Food Studies, 6(2), pp. 222-231. DOI: http://dx.doi.org/10.7455/ijfs/6.2.2017.a8. ISSN 21821054.

SINGLETON, V. L., ROSSI, J. A. 1965. Colorimetry of total phenolics with phosphomolybdic -phosphotun gstic acid reagents. American. Journal of Enology and Agriculture, 14, 3, pp. 144-158.

TORRI, L., PIOCHI, M., LAVELLI, V. AND MONTELEONE, E. 2015. Descriptive sensory analysis and consumers' preference for dietary fibre- and polyphenol-enriched tomato purees obtained using winery by-products. $L W T$ Food Science and Technology, 62(1), pp. 294-300. DOI: http://dx.doi.org/10.1016/j.lwt.2014.12.059. ISSN 00236438.

WÓJTOWICZ, A., ZALEWSKA-KORONA, M., JABŁOŃSKA-RYŚ, E. 2018 Chemical Characteristics and Physical Properties of Functional Snacks Enriched with Powdered Tomato. Pol. J. Food Nutr. Sci., 68, 3, pp. 251-261. DOI: http://dx.doi.org/10.1515/pjfns-2017-0028

WÜNSCHE, J., LAMBERT, CH., GOLA, U., BIESALSKI, H. K. 2018 Consumption of gluten free products increases heavy metal intake. NFS Journal, 12, pp. 11-15. DOI: http://dx.doi.org/10.1016/j.nfs.2018.06.001. ISSN 23523646. XIAO, J. 2018. Stability of dietary polyphenols: It's never too late to mend? Food and Chemical Toxicology, DOI: http://dx.doi.org/10.1016/j.fct.2018.03.051 